\title{
KEEFEKTIFAN PEMBELAJARAN KOOPERATIF STAD DAN TAI DITINJAU DARI AKTIVITAS DAN PRESTASI BELAJAR MATEMATIKA SISWA
}

\section{THE EFFECTIVENESS OF COOPERATIVE LEARNING OF STAD AND TAI IN TERMS OF THE ACTIVITIES AND MATHEMATICS LEARNING ACHIEVEMENT OF STUDENTS}

\author{
Rina Dyah Rahmawati, Ali Mahmudi \\ SD Muh Kleco Yogyakarta, Universitas Negeri Yogyakarta \\ rinadyah_r@yahoo.com, ali_uny73@yahoo.com
}

\begin{abstract}
Abstrak
Penelitian ini bertujuan untuk menentukan: (1) keefektifan pembelajaran kooperatif tipe STAD, (2) keefektifan pembelajaran kooperatif tipe TAI, dan (3) perbedaan keefektifan antara pembelajaran kooperatif tipe STAD dibandingkan pembelajaran kooperatif tipe TAI ditinjau dari aktivitas dan prestasi belajar siswa pada mata pelajaran matematika di kelas IV sekolah dasar. Penelitian ini merupakan penelitian eksperimen semu. Populasi penelitian ini adalah seluruh siswa kelas IV SD Muhammadiyah Kleco Yogyakarta dengan tiga kelas pararel. Dua kelas ditentukan secara acak sebagai sampel dari tiga kelas yang ada. Hasil penelitian adalah sebagai berikut. (1) Pembelajaran kooperatif tipe STAD efektif ditinjau dari aktivitas dan prestasi belajar siswa pada mata pelajaran matematika. (2) Pembelajaran kooperatif tipe TAI efektif ditinjau dari aktivitas dan prestasi belajar siswa pada mata pelajaran matematika. (3) Tidak terdapat perbedaan keefektifan antara pembelajaran kooperatif tipe STAD dibandingkan pembelajaran kooperatif tipe TAI ditinjau dari aktivitas dan prestasi belajar siswa pada mata pelajaran matematika di kelas IV sekolah dasar.
\end{abstract}

Kata kunci: model pembelajaran kooperatif tipe STAD, model pembelajaran kooperatif tipe TAI, aktivitas belajar matematika, dan prestasi belajar matematika.

\begin{abstract}
This study aimed to determine: (1) the effectiveness of STAD cooperative learning, (2) the effectiveness of TAI cooperative learning, and (3) the difference between the effectiveness of STAD cooperative learning and TAI cooperative learning in terms of the activities and mathematics learning achievement of fourth grade students of elementary schools. This is a quasi-experimental study. The study population was all fourth grade students of Muhammadiyah 3 Elementary School Kleco Yogyakarta with three parallel classes. Two classes were randomly assigned as samples of the three existing classes. The results are as follows. (1) The STAD cooperative learning is effective. (2) The cooperative learning of TAI type is effective. (3) There is no difference in the effectiveness between STAD cooperative learning and TAI cooperative learning in terms of the activities and achievement in mathematics of the fourth grade students of elementary schools.
\end{abstract}

Keywords: STAD Cooperative Learning Model, TAI Cooperative Learning Model, learning activities, and mathematics achievement. 


\section{Pendahuluan}

Mata pelajaran matematika perlu diberikan kepada semua peserta didik mulai dari sekolah dasar untuk membekali peserta didik dengan kemampuan berpikir logis, analitis, sistematis, kritis, dan kreatif, serta kemampuan bekerja sama. Kompetensi tersebut diperlukan agar peserta didik dapat memiliki kemampuan memeroleh, mengelola, dan memanfaatkan informasi untuk bertahan hidup pada keadaan yang selalu berubah, tidak pasti, dan kompetitif (BSNP, 2006, p.147).

Pada saat ini dunia pendidikan dihadapkan pada suatu paradigma kurikulum berbasis kompetensi. Sesuai dengan panduan KTSP (BSNP, 2006, p.5) kurikulum dengan basis kompetensi dalam praktiknya di kelas banyak melibatkan keaktifan dan juga kreativitas baik siswa maupun guru dalam kegiatan pembelajaran. Interaksi dalam suatu kegiatan pembelajaran diarahkan ke model interaksi multi arah, yaitu guru-siswa, siswa-guru, siswa-siswa, dan siswa-materi (Johnson \& Johnson, 1987, p.102). Tentu kemampuan siswa untuk mengungkapkan pengetahuan yang dimilikinya ataupun yang baru dipahaminya menjadi sangat penting.

Menurut Marsigit (2008) sebagian besar guru matematika masih mengimplementasikan pembelajaran matematika tradisional, yaitu pembelajaran matematika dengan mengandalkan metode tunggal ekspositori dengan siklus: menjelaskan, memberi contoh, mengajukan pertanyaan dan memberi tugas secara klasikal. Pada pembelajaran dengan pendekatan pembelajaran matematika tradisional tersebut, komunikasi siswa masih terbatas hanya pada jawaban verbal yang pendek atas berbagai pertanyaan yang diajukan oleh guru. Hal ini disebabkan pembelajaran terpusat pada guru. Kebiasaan siswa hanya mendengarkan, mengikuti contoh, dan mengerjakan soal-soal latihan tanpa terlibat dalam membangun konsep, prinsip, ataupun struktur berdasarkan pemikirannya sendiri. Satu hal lain pula yaitu kemauan siswa untuk bertanya sangat minim. Keterkekangan dalam setiap kegiatan pembelajaran tersebut akan membuat siswa bersikap tertutup. Akhirnya kebiasaan tersebut terus berkelanjutan dan menyebabkan siswa tidak terbiasa bersikap aktif dalam berinteraksi dengan guru ataupun dengan temannya, bahkan bersikap acuh tak acuh terhadap materi yang sedang dipelajarinya.
Senada dengan kondisi di atas, hasil studi Direktorat PLP (Widiharto, 2004, p.1) pada tahun 2002 menyebutkan bahwa meski adanya peningkatan mutu pendidikan yang cukup menggembirakan, tetapi pembelajaran dan pemahaman siswa SD pada beberapa materi pelajaran termasuk matematika menunjukkan hasil yang kurang memuaskan. Pembelajaran cenderung textbook oriented. Pembelajaran seakan abstrak dan dengan metode ceramah sehingga konsep-konsep akademik sulit dipahami. Sementara itu sebagian besar guru dalam mengajar masih kurang memerhatikan kemampuan berpikir siswa, atau dengan kata lain tidak melakukan pengajaran bermakna, metode yang digunakan kurang bervariasi, dan sebagai akibatnya motivasi belajar siswa menjadi sulit ditumbuhkan dan pola belajar cenderung menghafal dan mekanistis.

Untuk membantu mengatasi masalahmasalah yang tersebut di atas, maka diperlukan suasana belajar yang aktif, efektif, kreatif, dan menyenangkan agar siswa senantiasa aktif dalam belajar matematika. Sudah saatnya siswa diberi kesempatan yang seluas-luasnya untuk mengembangkan diri. Guru selayaknya menjadi fasilitator bagi siswa sehingga guru membantu siswa mengonstruk pengetahuan dengan mengarahkan interaksi sosial dan menyediakan representasi konsep seperti yang diutarakan Kauchack \& Eggen (1998, pp.192-193). Hal ini relevan dengan pandangan konstruktivisme bahwa siswa yang harus aktif membangun pengetahuan mereka.

Salah satu strategi pembelajaran matematika yang berorientasi pada pandangan konstruktivisme adalah belajar kooperatif. Sejalan dengan pendapat tersebut dalam pembelajaran kooperatif siswa tidak hanya dituntut untuk secara individual berupaya mencapai sukses atau berusaha mengalahkan rekan mereka, melainkan dituntut dapat bekerja sama untuk mencapai hasil bersama. Pada pembelajaran ini aspek sosial sangat menonjol dan siswa dituntut bertanggung jawab terhadap keberhasilan kelompoknya. Dalam belajar kooperatif siswa belajar dalam kelompok kecil yang bersifat heterogen dari segi gender, etnis, dan kemampuan akademik untuk saling membantu satu sama lain dalam mencapai tujuan bersama (Slavin, 1995, p.2).

Dengan pembelajaran matematika menggunakan pembelajaran kooperatif diharapkan di kelas siswa aktif secara individu, aktif berdiskusi, berani menyampaikan gagasan dari 
orang lain, kreatif mencari solusi dari suatu permasalahan yang dihadapi, memiliki sikap matematika dan kepercayaan diri yang tinggi dalam pembelajaran matematika, karena pembelajaran kooperatif dapat meningkatkan prestasi belajar dan sikap terhadap matematika siswa (Zakaria, Chin, \& Daud, 2010, p.274).

Selain dapat digunakan untuk siswa yang bersifat heterogen, pembelajaran kooperatif dapat digunakan di setiap tingkat kelas, dalam setiap mata pelajaran, dan dengan tugas apapun, seperti yang disampaikan Borich (2007, p.390) yaitu, "Many different forms of cooperative learning have been successfully used in classrooms of all grade levels and subject matter".

Santrock (2011, p.398) menambahkan bahwa hanya ketika peserta didik berada dalam kelompok kooperatiflah mereka kemungkinan tidak akan memilih bermain, interaksi positif sesama teman, dan perasaan positif tentang keputusan mereka adalah faktor motivasi di balik pilihan peserta didik untuk berada dalam kelompok belajar bersama.

Menurut Slavin (1995, p.43) penelitian tentang pembelajaran kooperatif merupakan penelitian pendidikan yang paling sukses. $\mathrm{Mu}$ raya dan Kimamo (2011, p.741) menambahkan bahwa pendekatan pembelajaran kooperatif memiliki nilai prestasi signifikan rata-rata lebih tinggi dalam tiga tingkat domain kognitif pengetahuan, pemahaman, dan penerapan dibandingkan dengan mereka yang diajarkan melalui metode mengajar reguler. Menurut Arends (2008, pp.5-6) model pembelajaran kooperatif dikembangkan untuk mencapai tiga tujuan yaitu: (1) Belajar kooperatif sangat menguntungkan baik bagi siswa yang memiliki kemampuan tinggi maupun rendah. Siswa berkemampuan tinggi dapat menjadi tutor bagi siswa yang berkemampuan rendah. Dalam proses ini siswa berkemampuan lebih tinggi secara akademis mendapatkan keuntungan, karena pengetahuannya dapat lebih mendalam; (2) Belajar kooperatif menyajikan peluang bagi siswa dari latar belakang dan kondisi sosial, untuk bekerja saling bergantung pada tugas-tugas rutin, dan melalui struktur penghargaan kooperatif dapat belajar menghargai satu sama lain; (3) Belajar kooperatif bertujuan mengajarkan pada siswa keterampilan-keterampilan kerja sama dan kolaborasi. Ini adalah keterampilan yang penting yang harus dimiliki dalam suatu masyarakat.

Ada beberapa metode pembelajaran kooperatif yang dapat diadaptasikan pada seba- gian besar dan tingkat kelas, di antaranya adalah Student Teams Achievement Division (STAD) dan Team Assisted Individualization (TAI).

STAD merupakan strategi pembelajaran yang populer karena penerapannya yang luas di berbagai bidang studi (termasuk matematika, membaca, dan ilmu sosial dan tingkat kelas), hal ini dijelaskan oleh Moore (2009, p.205). Metode pembelajaran kooperatif STAD termasuk model pembelajaran yang paling sederhana dan merupakan model yang paling baik untuk permulaan bagi guru yang baru menggunakan pendekatan kooperatif seperti yang diungkapkan oleh Slavin (1995, p.71). Kesederhanaan dari metode tersebut meliputi penyajian materi oleh guru dengan metode ceramah atau demonstrasi yang masih dimungkinkan dan kemampuan siswa mengomunikasikan hasil kerja atau hasil diskusi melalui presentasi ke seluruh kelas yang dilatihkan secara bertahap. Proses kegiatan ini sederhana sehingga dapat dilakukan oleh siswa sekolah dasar. Gagasan utama dari STAD adalah

untuk memotivasi siswa supaya saling mendukung dan membantu satu sama lain dalam menguasai kemampuan yang diajarkan oleh guru yaitu materi-materi untuk memahami konsep-konsep materi pelajaran matematika yang membutuhkan kemampuan bekerja sama, berpikir kritis, mengembangkan sikap sosial siswa yang sesuai dengan salah satu tujuan pendidikan karakter, dan materi-materi yang berkaitan dengan pemecahan masalah (problem solving).

Perencanaan pembelajaran kooperatif tipe STAD disusun berdasarkan langkahlangkah dalam pembelajaran kooperatif. Hal tersebut seperti yang dijabarkan oleh Arends \& Kilcher (2010, p.306) bahwa, cooperative learning is a teaching model or strategy that is caracterized by cooperative task, and reward structures, and requires students to be actively engaged in discus-sion, debate, tutoring, and teamwork.

Pembelajaran kooperatif adalah model atau strategi pembelajaran yang dicirikan oleh tugas kooperatif, tujuan, dan struktur penghargaan, dan membutuhkan siswa untuk secara aktif terlibat dalam diskusi, debat, les, dan kerjasama tim. Langkah-langkah tersebut merupakan siklus yang tetap dalam kegiatan pembelajaran kooperatif tipe STAD ini seperti yang dikemukakan oleh Slavin (1995, p.287) sebagai berikut: (1) Presentasi Kelas. Sebagai peng- 
antar guru dapat memerkenalkan materi dalam STAD. Penyajian materi ini dapat dengan verbal langsung disampaikan oleh guru atau dapat pula melalui bahan bacaan atau audiovisual; (2) Tim. Tim terdiri dari empat atau lima siswa. Dalam hal ini tim berisi kelompok heterogen baik dalam hal kinerja akademik, ras, dan jenis kelamin. Siswa bekerja sama dalam kelompok masing-masing untuk menguasai materi pelajaran atau menyelesaikan tugas. Fungsi dari tim ini adalah memastikan bahwa semua anggota tim benar-benar belajar, dan lebih khususnya lagi, adalah untuk memersiapkan anggotanya untuk dapat mengerjakan kuis dengan baik. Setelah menyampaikan materi, tim berkumpul untuk memelajari LKS atau materi lainnya. Yang paling sering terjadi, pembelajaran STAD melibatkan pembahasan permasalahan bersama, membandingkan jawaban dan mengoreksi tiap kesalahan pemahaman apabila ada anggota tim yang membuat kesalahan; (3) Kuis. Setelah satu atau dua periode presentasi oleh guru dan praktik tim, siswa mengerjakan kuis atau penilaian lainnya secara individual. Dalam hal ini siswa tidak diperbolehkan saling membantu dalam mengerjakan kuis. Dengan demikian setiap siswa memunyai tanggung jawab masing-masing untuk menguasai materi; (4) Skor kemajuan siswa. Adanya skor kemajuan siswa ini adalah agar tercapai tujuan kinerja apabila mereka dapat melakukan kinerja yang lebih giat dan memberikan kinerja yang lebih baik dari sebelumnya; (5) Penghargaan kelompok. Skor kelompok dihitung berdasarkan poin peningkatan kelompok, pemberian sertifikat, laporan berkala kelas, atau papan buletin sebagai penghargaan skor tertinggi kelompok.

Pembelajaran kooperatif TAI juga merupakan metode pembelajaran kooperatif yang dikembangkan oleh Slavin. TAI dirancang khusus untuk mengajarkan Matematika. Menurut Slavin (1995, p.189) pembelajaran matematika dengan metode TAI diprakarsai sebagai usaha merancang sebuah bentuk pengajaran individual yang dapat menyelesaikan masalahmasalah yang membuat metode pengajaran individual menjadi tidak efektif. Widyantini (2006, p.8) mengemukakan bahwa pembelajaran kooperatif tipe TAI mengombinasikan keunggulan pembelajaran kooperatif dan pembelajaran individual. Tipe ini dirancang untuk mengatasi kesulitan belajar siswa secara individual. Ciri khas pada tipe TAI ini adalah setiap siswa secara individual belajar materi pembelajaran yang sudah dipersiapkan oleh guru.
Sesuai yang diuraikan Slavin (1995, p.102) bahwa model pembelajaran kooperatif tipe TAI memiliki delapan bagian tetap dalam kegiatan pembelajaran, yaitu: (1) Teams yaitu pembentukan kelompok heterogen yang terdiri dari 4 sampai 5 siswa; (2) Placement Test yaitu pemberian pretest kepada siswa atau melihat ratarata nilai harian siswa agar guru mengetahui kelemahan siswa pada bidang tertentu; (3) Curriculum Materials yaitu materi yang akan diselesaikan oleh siswa sesuai dengan kurikulum yang ada; (4) Team Study yaitu yaitu tahapan tindakan belajar yang harus dilaksanakan oleh kelompok siswa dan guru memberikan bantuan secara individual kepada siswa yang membutuhkan. Para siswa mengerjakan unit-unit mereka dalam kelompok mereka atau dengan kata lain siswa diberikan untuk mengerjakan soal secara individu terlebih dahulu kemudian setelah itu mendiskusikan hasilnya dengan kelompok masing-masing; (5) Team Score and Team Recognition yaitu pemberian skor terhadap hasil kerja kelompok dan memberikan kriteria penghargaan terhadap kelompok yang berhasil secara cemerlang dan kelompok yang dipandang kurang berhasil dalam menyelesaikan tugas; (6) Teaching group yaitu pemberian materi secara singkat dari guru menjelang pemberian tugas kelompok; (7) Fact test yaitu pelaksanaan tes-tes kecil berdasarkan fakta yang diperoleh siswa; (8) Whole-Class Units yaitu pemberian materi oleh guru kembali diakhir waktu pembelajaran dengan strategi pemecahan masalah.

Berdasarkan uraian di atas strategi dalam kegiatan pembelajaran turut menentukan hasil belajar seperti yang dikemukakan oleh Hudojo (1988, p.96) bahwa strategi pembelajaran akan menentukan terjadinya proses belajar yang selanjutnya menentukan hasil belajar. Dalam strategi pembelajaran, guru mengajar dan peserta didik belajar adalah dua proses yang berbeda. Artinya, ketika guru mengajar belum tentu peserta didiknya belajar. Ketika peserta didik banyak melakukan aktivitas, itulah sebenarnya saat peserta didik belajar. Hal ini sesuai dengan arti pembelajaran menurut Suherman \& Winataputra (1992, p.90) yaitu upaya penataan lingkungan belajar yang memungkinkan peserta didik dapat belajar. Dalam rangka penataan dan pemanfaatan lingkungan belajar tersebut, guru sebagai pengarah dan memberi kemudahan belajar dituntut untuk dapat melakukan aktivitas, yaitu (1) menyajikan sesuatu; (2) menumbuhkembangkan proses ber- 
pikir peserta didik; (3) membina interaksi sosial peserta didik; (4) mengajar bagaimana belajar.

Peran guru tersebut sangat bergantung dari strategi pembelajaran yang digunakan dan materi yang sedang diajarkannya. Seperti halnya pada materi geometri di kelas IV sekolah dasar yaitu sifat bangun ruang sederhana dan hubungan antarbangun. Materi ini terdapat dalam standar isi untuk satuan pendidikan dasar dan menengah 2006 mata pelajaran matematika. Materi ini terdiri dari empat sub pokok bahasan, yaitu (1) sifat-sifat bangun ruang sederhana; (2) jaring-jaring balok dan kubus; (3) identifikasi benda-benda dan bangun datar simetris; (4) Pencerminan suatu bangun datar. Dalam jurnal penelitian pendidikan, Roebyanto \& Harmini (2003, p.18) berpendapat bahwa kurang berhasilnya para peserta didik dalam belajar matematika, khususnya belajar geometri, dapat disebabkan oleh beberapa faktor, baik dari secara internal maupun eksternal peserta didik. Dari faktor internal dapat disebabkan peserta didik sering banyak menghafal suatu konsep, tanpa disadari dengan pemahaman dan kebermaknaan.

Melalui pembelajaran kooperatif tipe STAD dan TAI dengan materi geometri, ketika peserta didik belajar dapat saling memberi informasi dalam kelompoknya, bahkan antar kelompok. Salah satu anggota kelompok mungkin menguasai informasi A akan menjelaskannya kepada teman lainnya. Peserta didik lain dalam kelompok tersebut menguasai informasi B akan menjelaskan pula informasi tersebut. Demikian seterusnya sehingga informasi dan pengetahuan yang diperlukan akan dapat dipenuhi dan mereka akan merasa saling membutuhkan satu sama lain. Sifat menghargai orang lain akan terbentuk sebagai salah satu tujuan afektif dalam pembelajaran.

Tujuan pembelajaran yang meliputi aspek kognitif, afektif, dan psikomotor menjadi sangat diperhatikan pada pembelajaran yang banyak digunakan pada saat ini. Pembelajaran kooperatif misalnya. Hal ini pun dalam Kurikulum Berbasis Kompetensi (KBK) sangat diperhatikan. Oleh karena itu peneliti termotivasi untuk meneliti keefektifan strategi pembelajaran kooperatif STAD dan TAI pada pelajaran matematika di kelas IV SD dengan memfokuskan pokok bahasan geometri. Sedangkan tujuan dari penelitian ini adalah: (1) menentukan keefektifan pembelajaran kooperatif tipe STAD ditinjau dari aktivitas dan prestasi belajar siswa pada mata pelajaran matematika di kelas IV SD; (2) menentukan keefek- tifan pembelajaran kooperatif tipe TAI ditinjau dari aktivitas dan prestasi belajar siswa pada mata pelajaran matematika di kelas IV SD; dan (3) menentukan perbedaan keefektifan antara pembelajaran kooperatif tipe STAD dibandingkan pembelajaran kooperatif tipe TAI ditinjau dari aktivitas dan prestasi belajar siswa pada mata pelajaran matematika di kelas IV SD.

\section{Metode}

Penelitian ini menggunakan pendekatan eksperimen semu (quasi-experiment). Dalam penelitian ini, peneliti tidak membuat kelaskelas baru, tetapi menggunakan kelas-kelas sebagaimana adanya. Peneliti menggunakan kelompok-kelompok untuk perlakuan karena peneliti tidak dapat memilih individu-individu secara acak.

Desain penelitian yang digunakan adalah quasi eksperiments dengan desain $A$ Counterbalanced Design with Two Treatments. Dalam penelitian ini, Kelas A diberi perlakuan pembelajaran kooperatif tipe STAD dan kelas B diberi perlakuan pembelajaran kooperatif tipe TAI. Pada masing-masing kelas tersebut dilakukan pretest dan posttest.

Tahap-tahap yang dilalui dalam penelitian adalah sebagai berikut: (1) mengajukan perijinan ke sekolah; (2) menyusun instrumen penelitian dan memvalidasi instrumen penelitian oleh dosen ahli; (3) melakukan uji coba instrumen penelitian; (4) estimasi reliabilitas instrumen penelitian; (5) revisi instrumen penelitian sesuai dengan saran perbaikan; (6) mengadakan pertemuan dengan guru dilanjutkan dengan pembekalan pembelajaran kooperatif tipe STAD dan pembelajaran kooperatif tipe TAI; (7) melaksanakan pretest; (8) melaksanakan observasi model pembelajaran kooeperatif STAD dan TAI pada masing-masing kelas eksperimen; (9) melaksanakan posttest setelah model pembelajaran kooperatif tipe STAD dan TAI pada masing-masing kelas eksperimen selesai dilaksanakan; dan (10) analisis data.

\section{Tempat dan Waktu Penelitian}

Penelitian ini dilakukan di SD Muhammadiyah Kleco Yogyakarta. Penelitian ini dilaksanakan pada bulan April hingga Mei tahun ajaran 2012/2013 dengan membelajarkan matematika materi pokok geometri yaitu memahami sifat bangun ruang sederhana dan hubungan antarbangun datar.

Populasi dan Sampel Penelitian 
Populasi dalam penelitian ini adalah seluruh siswa kelas IV SD Muhammadiyah Kleco Yogyakarta dengan tiga kelas pararel yaitu kelas IV Shidiq, IV Amanah, dan IV Tabligh yang seluruh siswanya sebanyak 65 anak. Penentuan sampel kelas dilakukan melalui undian dari tiga kelas yang ada sebagaimana yang dijelaskan oleh dua kelas dari tiga kelas tersebut menjadi kelas eksperimen yaitu kelas IV Shidiq dan kelas IV Amanah, masing-masing terdiri dari 23 siswa dan 21 siswa.

Instrumen Penelitian

Instrumen pengumpulan data yang digunakan dalam penelitian ini adalah instrumen aktivitas siswa meliputi lembar observasi, instrumen untuk prestasi belajar dengan menggunakan tes prestasi belajar matematika.

Lembar observasi aktivitas siswa digunakan untuk memeroleh data tentang aktivitas yang dilakukan siswa selama kegiatan pembelajaran berlangsung. Instrumen ini diberikan kepada seorang pengamat pada setiap kelompok dan pengamat tersebut menuliskan kode aspek pengamatan yang muncul pada kolom sesuai periode waktu selama kegiatan pembelajaran berlangsung.

Tes digunakan untuk mengukur prestasi belajar matematika siswa. Tes yang digunakan berupa tes tertulis berbentuk pilihan ganda dan uraian. Instrumen penelitian ini terdiri dari pretest dan posttest. Pretest digunakan untuk mengetahui prestasi belajar sebelum metode pembelajaran kooperatif diterapkan. Sedangkan posttest digunakan untuk mengetahui prestasi belajar setelah metode pembelajaran kooperatif diterapkan.

\section{Validitas dan Reliabilitas Instrumen}

Validitas adalah persyaratan bagi penelitian yang baik. Bukti validitas instrumen yang diperlukan dalam penelitian ini adalah validitas isi (content validity) dan validitas kontruk (construct validity). Validitas isi (content validity) instrumen menunjukkan sejauh mana item-item dalam tes mencakup keseluruhan kawasan isi yang hendak diukur oleh tes itu. Validitas isi instrumen tes dapat diketahui dari kesesuaian instrumen tes tersebut dengan standar kompetensi dan kompetensi dasar, sedangkan lembar aktivitas siswa diketahui dari kesesuaian instrumen yang telah dikembangkan dengan kisi-kisinya. Setelah instrumen dikonstruksi, kemudian dikonsultasikan dengan validator ahli.
Validitas konstruk (construct validity) mengacu pada sejauh mana suatu instrumen mengukur trit atau konstruk teoritik yang hendak diukur. Untuk memeroleh bukti validitas konstruk, maka setelah disetujui oleh dosen pembimbing dan dosen ahli, instrumen tes diujicobakan kepada 28 orang siswa. Data yang diperoleh dari hasil uji coba tersebut dianalisis dengan korelasi Product Moment. Analisis dilakukan dengan bantuan SPSS 17 for windows.

Hasil analisis ujicoba instrumen tes prestasi belajar menggunakan SPSS 17.0 for windows menunjukkan bahwa dari 25 butir soal pilihan ganda pada instrumen prestasi belajar siswa, sebanyak 21 memenuhi syarat kevalidan dengan nilai signifikansi lebih kecil dari 0,05. Butir soal 1, 6, 12, dan 21 sesuai hasil analisis menggunakan SPSS 17.0 for windows menunjukkan nilai signifikansi lebih besar dari 0,05 sehingga perlu dilakukan revisi agar skor korelasi butir soal 1, 6, 12, dan 21 layak. Untuk hasil analisis 5 butir soal uraian (essay) sebanyak 4 soal memenuhi syarat kevalidan. Butir soal 4 perlu dilakukan revisi karena skor korelasi butir hasil analisis menggunakan SPSS 17.0 for windows menunjukkan nilai signifikansi lebih dari 0,05.

Tujuan utama estimasi reliabilitas adalah untuk menentukan seberapa besar variabilitas yang terjadi akibat adanya kesalahan pengukuran dan seberapa besar variabilitas skor tes sebenarnya sesuai yang diungkapkan Daniel (2004, p.71), Reliability then refers to the extent to which test scores are free of measurement error. Untuk mengukur tingkat keajegan soal maka digunakan perhitungan Alpha Cronbach dianalisis menggunakan bantuan SPSS 17.0 for Windows.

Berdasarkan hasil perhitungan diperoleh koefesien reliabilitas instrumen butir soal pilihan ganda pada tes prestasi belajar matematika siswa setelah dianalisis nilai Alpha sebesar 0,726. Feldt dan Brehman (Kartowagiran, 2011, p.11) berpendapat bahwa suatu instrumen yang memiliki koefisien realibilitas lebih atau sama dengan 0,7 sudah dikatakan reliabel. Jadi, instrumen soal pilihan ganda yang digunakan dinyatakan reliabel dan dapat digunakan untuk mengukur prestasi belajar siswa. Koefisien reliabilitas instrumen butir soal uraian (essay) pada tes prestasi belajar matematika siswa setelah dianalisis nilai Alpha sebesar 0,60. Menurut Nunnaly (Kartowagiran, 2011, p.11) untuk soal pilihan uraian yang memiliki koefisien reliabilitas 0,60-0,70 sudah dikatakan 
baik. Jadi, instrumen soal uraian (essay) yang digunakan dinyatakan reliabel dan dapat digunakan untuk mengukur prestasi belajar siswa.

Teknik Analisis Data

Data penelitian yang dianalisis adalah data kondisi awal dan akhir pada aspek kegiatan pembelajaran di kelas. Data kondisi awal untuk mengetahui gambaran awal kedua kelompok siswa, dalam hal ini dilakukan uji asumsi diantaranya uji normalitas dan uji homogenitas. Uji normalitas dilakukan terhadap data yang diperoleh baik sebelum maupun setelah perlakuan meliputi data tes prestasi belajar siswa dan lembar observasi aktivitas belajar siswa dalam pembelajaran matematika, baik pada kelompok yang menggunakan model pembelajaran kooperatif tipe STAD maupun pembelajaran kooperatif tipe TAI. Uji homogenitas bertujuan untuk mengetahui suatu subjek penelitian berasal dari populasi yang homogen atau tidak homogen. Uji homogenitas ini dilakukan terhadap data hasil observsi aktivitas belajar matematika siswa dan prestasi belajar siswa, baik kepada kelompok eksperimen satu maupun maupun kelompok eksperimen dua. Selanjutnya kondisi akhir untuk mendeskripsikan data perbedaan efektifitas model pembelajaran kooperatif tipe STAD dan tipe TAI.

Keefektifan model pembelajaran ditinjau dari prestasi belajar matematika siswa ditentukan berdasarkan kriteria ketuntasan minimal (KKM) belajar matematika di SD Muhammadiyah Kleco 3 yaitu siswa dikatakan tuntas belajar matematika apabila mencapai nilai 70,00 untuk skala seratus, maka kriteria pencapaian tujuan pembelajaran aspek prestasi belajar matematika siswa yaitu 70,00. Untuk model pembelajaran kooperatif STAD dan TAI dikatakan efektif apabila rerata prestasi belajar siswa lebih dari nilai KKM yaitu 70,0.

Kategori keefektifan model pembelajaran ditinjau dari aktivitas belajar siswa diperoleh dengan menggunakan instrumen non tes yang berbentuk checklist dengan skala likert. Siswa dikatakan aktif dalam pembelajaran apabila mencapai kriteria tinggi dalam pencapaian skor. Untuk model pembelajaran kooperatif tipe STAD dan TAI dikatakan efektif apabila rerata aktivitas belajar matematika siswa lebih dari skor minimal pada kriteria tinggi. Data yang diperoleh digolongkan dalam kriteria berdasarkan Tabel 1 untuk aktivitas belajar siswa dengan model pembelajaran STAD dan tabel 2 untuk model pembelajaran TAI.
Tabel 1.Kategorisasi Aktivitas Belajar Siswa dengan Model Pembelajaran STAD

\begin{tabular}{|c|c|c|c|}
\hline No & Interval & Skor & Kriteria \\
\hline 1 & $\begin{array}{c}\mathrm{Mi}+1,5 \mathrm{Si}<\mathrm{X} \leq \mathrm{Mi} \\
+3 \mathrm{Si}\end{array}$ & $15<X \leq 18$ & $\begin{array}{l}\text { Sangat } \\
\text { tinggi }\end{array}$ \\
\hline 2 & $\begin{array}{c}\mathrm{Mi}+0,5 \mathrm{Si}<\mathrm{X} \leq \mathrm{Mi} \\
+1,5 \mathrm{Si}\end{array}$ & $13<X \leq 15$ & Tinggi \\
\hline 3 & $\begin{array}{c}\mathrm{Mi}-0,5 \mathrm{Si}<\mathrm{X} \leq \mathrm{Mi} \\
+0,5 \mathrm{Si}\end{array}$ & $11<X \leq 13$ & Sedang \\
\hline 4 & $\begin{array}{c}\mathrm{Mi}-1,5 \mathrm{Si}<\mathrm{X} \leq \mathrm{Mi} \\
-0,5 \mathrm{Si}\end{array}$ & $9<X \leq 11$ & Rendah \\
\hline 5 & $\begin{array}{c}\mathrm{Mi}-3 \mathrm{Si}<\mathrm{X} \leq \mathrm{Mi}- \\
1,5 \mathrm{Si}\end{array}$ & $6<X \leq 9$ & $\begin{array}{l}\text { Sangat } \\
\text { rendah }\end{array}$ \\
\hline
\end{tabular}

Sedangkan data yang diperoleh digolongkan dalam kriteria berdasarkan tabel 2 berikut untuk aktivitas belajar siswa dengan model pembelajaran TAI.

Tabel 2.Kategorisasi aktivitas belajar siswa dengan model pembelajaran TAI

\begin{tabular}{|c|c|c|c|}
\hline No & Interval & Skor $(X)$ & Kriteria \\
\hline 1. & $\begin{array}{c}\mathrm{Mi}+1,5 \mathrm{Si}<\mathrm{X} \leq \mathrm{Mi}+ \\
3 \mathrm{Si}\end{array}$ & $\begin{array}{c}17<X \\
\leq 21\end{array}$ & $\begin{array}{l}\text { Sangat } \\
\text { tinggi }\end{array}$ \\
\hline 2. & $\begin{array}{c}\mathrm{Mi}+0,5 \mathrm{Si}<\mathrm{X} \leq \mathrm{Mi}+ \\
1,5 \mathrm{Si}\end{array}$ & $\begin{array}{c}16<X \\
\leq 18\end{array}$ & Tinggi \\
\hline 3. & $\begin{array}{c}\mathrm{Mi}-0,5 \mathrm{Si}<\mathrm{X} \leq \mathrm{Mi}+ \\
0,5 \mathrm{Si}\end{array}$ & $\begin{array}{c}13<X \\
\leq 16\end{array}$ & Sedang \\
\hline 4. & $\begin{array}{c}\mathrm{Mi}-1,5 \mathrm{Si}<\mathrm{X} \leq \mathrm{Mi}- \\
0,5 \mathrm{Si}\end{array}$ & $\begin{array}{c}11<X \leq \\
13\end{array}$ & Rendah \\
\hline 5. & $\begin{array}{c}\mathrm{Mi}-3 \mathrm{Si}<\mathrm{X} \leq \mathrm{Mi}- \\
1,5 \mathrm{Si}\end{array}$ & $7<X \leq 11$ & $\begin{array}{l}\text { Sangat } \\
\text { rendah }\end{array}$ \\
\hline
\end{tabular}

Penskoran untuk skala aktivitas belajar siswa pada model pembelajaran STAD dalam penelitian ini memiliki rentang antara 6 sampai dengan 18. Untuk menentukan kriteria hasil pengukurannya digunakan klasifikasi berdasarkan rata-rata ideal $(\mathrm{Mi})$ dan standar deviasi ideal $(\mathrm{Si}) . \mathrm{Mi}=(6+18) / 2=12$ dan $\mathrm{Si}=(18-$ 6) $/ 6=2$. Sedangkan skala aktivitas belajar siswa pada model pembelajaran TAI dalam penelitian ini memiliki rentang antara 7 sampai dengan 21. Untuk menentukan kriteria hasil pengukurannya digunakan klasifikasi berdasarkan rata-rata ideal (Mi) dan standar deviasi ideal $(\mathrm{Si}) \cdot \mathrm{Mi}=(7+21) / 2=14$ dan $\mathrm{Si}=(21-$ 7) / $6=2,33$. 
Setelah memeroleh data pengukuran aktivitas belajar siswa, skor total masing-masing unit dikategorikan berdasarkan kriteria pada Tabel 1 dan Tabel 2 di atas. Total skor semua unit yang telah terkumpul kemudian dihitung presentasenya untuk masing-masing kategori sangat tinggi, tinggi, sedang, rendah, dan sangat rendah.

Untuk mengetahui kefektifan masingmasing model pembelajaran kooperatif tipe STAD dan tipe TAI ditinjau dari aktivitas belajar dan prestasi belajar maka dilakukan analisis dengan one sample t-test menggunakan bantuan SPSS 17 for Windows, yaitu untuk melihat keefektifan keseluruhan model pembelajaran terhadap prestasi belajar siswa dan aktivitas siswa dalam pembelajaran matematika. Kriteria keputusannya adalah $\mathrm{H}_{0}$ ditolak jika nilai signifikan kurang dari dari 0,05. Hal tersebut menunjukkan resiko kesalahan dalam mengambil keputusan untuk menolak hipotesis yang benar sebanyak-banyaknya 5\%.

Untuk menyelidiki perbedaan efektifitas model pembelajaran tipe STAD dan tipe TAI ditinjau dari prestasi belajar siswa dan aktivitas belajar siswa dalam pembelajaran matematika dilakukan dengan uji multivariat kemudian dilanjutkan dengan uji univariat yaitu uji $t$ untuk menentukan variabel mana yang berkontribusi terhadap perbedaan keseluruhan. Untuk analisis data multivariat, data yang dianalisis adalah data yang diperoleh dari pretest, posttest, dan lembar aktivitas sebelum dan setelah perlakuan.

Perhitungan untuk menguji hipotesis kondisi awal dan kondisi akhir di atas menggunakan uji multivariat menggunakan statistik Hotelling's $T^{2}$. Pengujian dilakukan menggunakan bantuan SPSS 17.0 for Windows sehingga kriteria keputusannya menolak $\mathrm{H}_{01}$ jika $p$-value $<0,05$.

Jika uji hipotesis multivariat kondisi akhir menyatakan bahwa terdapat perbedaan efektifitas model pembelajaran tipe STAD dengan tipe TAI ditinjau dari prestasi belajar matematika siswa dan aktivitas belajar siswa dalam pembelajaran matematika, maka dilakukan uji lanjut yaitu statistik uji $t$ univariat dengan asumsi yang harus dipenuhi adalah data berdistrubusi normal dan homogen.

Pengujian hipotesis di atas akan diuji menggunakan uji $t$ univariat. Kriteria yang digunakan adalah kriteria Boferroni dengan taraf signifikansi $\alpha / p(p=2)$, jadi $\alpha=0,05 \%$ untuk masing-masing uji $t$ digunakan kriteria
$0,05 / 2=0,025$. Pengujian dilakukan menggunakan bantuan SPSS 17.0 for Windows sehingga kriteria keputusannya menolak $\mathrm{H}_{01}$ jika $p<$ 0,05 .

\section{Hasil Penelitian}

Beberapa hal yang diselidiki dalam penelitian ini diantaranya adalah menentukan keefektifan antara pembelajaran kooperatif tipe STAD dibandingkan pembelajaran kooperatif tipe TAI ditinjau dari aktivitas dan prestasi belajar siswa pada mata pelajaran matematika di kelas IV sekolah dasar. Prestasi siswa pada penelitian ini merupakan tingkat keberhasilan siswa dalam memelajari materi pelajaran sebagai akibat dari perubahan tingkah laku setelah mengikuti pembelajaran kooperatif STAD dan TAI sesuai tujuan pembelajaran yang ingin dicapai yang diukur dengan sebuah tes. Hal ini mengacu pada pendapat Sugihartono, dkk (2007, p.130) yang menyatakan bahwa prestasi belajar adalah hasil pengukuran yang berwujud angka maupun pernyataan yang mencerminkan tingkat penguasaan materi pelajaran bagi para siswa. Berdasar penjelasan tersebut prestasi belajar dapat diketahui jika telah dilakukan penilaian terhadap hasil belajar siswa. Pada penelitian ini, hasil belajar yang dimaksud adalah hasil belajar kognitif yang ditunjukkan dengan skor.

Untuk aktivitas siswa dalam model pembelajaran kooperatif STAD dan TAI melibatkan semua siswa yang berperan aktif dalam proses kegiatan belajar mengajar. Keterlibatan siswa selama proses pembelajaran kooperatif meliputi aspek-aspek yang dikembangkan oleh Paul D. Dierich (Sardiman, 2004, p.101). Aspek-aspek tersebut adalah visual activities, oral activities, listening activities, writing activities, drawing activities, motor activities, mental activities, dan emotional activities.

Aktivitas siswa yang dilakukan pada aspek visual (visual activities) adalah siswa dapat melakukan praktikum dengan baik sesuai dengan petunjuk yang tertera pada lembar kerja siswa.

Aktivitas siswa yang dilakukan pada aspek lisan (oral activities) adalah siswa mengajukan pertanyaan kepada guru tentang materi dan siswa mengomunikasikan hasil kerja dengan teman kelompok dan. Siswa tidak secara individu menyelesaikan kegiatan pada LKS, tetapi mengomunikasikannya dengan teman sekelompok sehingga terbangun kerja sama yang seimbang dengan masing-masing anggota kelompok. Dalam aktivitas ini siswa juga me- 
lakukan diskusi. Kegiatan ini juga melibatkan aktivitas mendengarkan (listening activities). Kegiatan ini mendorong siswa untuk terbiasa menyampaikan pendapatnya baik hal-hal yang belum dipahami dan perlu ditanyakan maupun hal-hal yang sudah dipahaminya. Siswa juga terbiasa menyampaikan gagasannya tanpa rasa takut dan khawatir apabila gagasannya salah atau tidak diterima oleh orang lain. Kegiatan yang dilakukan siswa dengan mendiskusikan masalah yang ada menunjukkan bahwa adanya komunikasi antara siswa dengan guru.Selain itu kepercayaan diri siswa dalam memresentasikan ide maupun gagasan membuktikan bahwa siswa memiliki keperyaan diri yang tinggi.

Aktivitas lainnya adalah menulis (writing activities). Pada kegiatan ini siswa menulis penyelesaian dari permasalahan pada lembar kegiatan siswa. Dengan menuliskan penyelesaian secara rapi dan sistematis, siswa dapat mengomunikasikan penyelesaian dari permasalahan melalui tulisan.Penyelesaian dari permasalahan pada lembar kegiatan siswa yang menjadi gagasannya tidak saja diungkapkan secara lisan tapi dituangkan secara tulisan sehingga menjadi dokumentasi atau portofolio kegiatan pembelajaran.

Aktivitas siswa pada aspek menggambar (drawing activities) dilakukan dengan mewarnai atau menggambar hal-hal pada materi pokok yang sesuai dengan kompetensi dasar. Siswa menyelesaikan permasalahan pada kegiatan pembelajaran dengan mewarnai atau menggambar sesuai dengan petunjuk pada Lembar kegiatan siswa. Dengan aktivitas pada aspek menggambar melatih siswa untuk menuangkan imajinasinya dan menggambarkan sesuatu yang abstrak menjadi konkrit.

Aktvitas siswa pada aspek motorik (motor activites) adalah siswa dapat memanfaatkan alat peraga dalam pembelajaran. Pada setiap kegiatan terdapat alat peraga sesuai dengan yang dibutuhkan pada kompetensi dasar. Siswa memanfaatkan alat peraga yang ada untuk mengetahui konsep melalui benda nyata yang berhubungan dengan kompetensi dasar yang berkaitan.

Dalam aktivitas yang berkaitan dengan aspek mental (mental activities), aktivitas yang dilakukan siswa adalah mencari penyelesaian terhadap permasalahan yang disajikan dalam LKS. Selain dengan bimbingan guru, siswa melihat hubungan atau keterkaitan antara masalah yang disajikan dengan matematika yang lebih bersifat formal. Siswa memelajari materi bangun ruang dengan melipat kertas, memotong, menggunting, memberi tanda, mewarnai, dan menggambar.

Kegiatan-kegiatan yang dilakukan siswa secara berkelompok atau diskusi dengan bimbingan guru menunjukkan adanya interaksi dalam proses pembelajaran matematika. Interaksi antar siswa berupa negoisasi, penjelasan, pembenaran, pernyataan setuju dan tidak setuju. Interaksi ini menimbulkan aktivitas mental (mental activities) yang dilakukan siswa dengan memberikan tanggapan atapun usulan dan berusaha mencari hubungan dari setiap pengetahuan yang diperoleh siswa. Aktivitas-aktivitas selama mengikuti kegiatan pembelajaran. Aktivitas siswa dalam aspek emosional (emotional activities) sangat baik dengan keterkaitan siswa selama mengikuti kegiatan pembelajaran dan sikap siswa yang selalu siap dalam mengikuti kegiatan pembelajaran.

Data-data yang diperoleh selama penelitian kemudian dianalisis untuk mendukung pembahasan hasil penelitian yang telah dilaksanakan pada dua kelas di Sekolah Dasar Muhammadiyah Kleco Yogyakarta. Data-data yang dimaksud dikelompokkan dalam empat kategori dengan empat variabel penelitian. Adapun deskripsi hasil penelitian dari masing-masing variabel, yaitu sebagai berikut.

Data observasi aktivitas belajar matematika kelas eksperimen I dan II dengan menerapkan model pembelajaran kooperatif tipe STAD dan model pembelajaran kooperatif tipe TAI.

Data tentang aktivitas pembelajaran pada kelas eksprimen I dengan penerapan model pembelajaran kooperatif tipe STAD diperoleh melalui pengamatan dengan menerapkan rating scale dari tiap aspek yang diamati terhadap pembelajaran yang dilaksanakan di kelas. Dalam pelaksanaannya observasi dilakukan oleh 5 orang yang mengamati aktifitas belajar matematika siswa. Berikut deskripsi hasil pengamatan terhadap aktivitas pembelajaran Matematika dengan model STAD.

Secara umum, observasi pembelajaran pada kelas eksperimen 1 dengan model STAD termasuk dalam kategori sangat tinggi. Hal ini ditunjukkan dengan perolehan rata-rata total skor semua kelompok selama 4 kali pertemuan adalah 15,34. Sedangkan untuk aktivitas belajar pada kelas eksperimen dua dengan model TAI termasuk dalam kategori tinggi. Hal ini ditunjukkan dengan perolehan rata-rata total skor 
semua kelompok selama 4 kali pertemuan adalah 16,29.

Berdasarkan hasil pengamatan aktivitas belajar matematika siswa dengan mengacu pada kriteria pembelajaran yang aktif yang telah ditentukan sebelumnya, pembelajaran matematika dengan menggunakan pendekatan TAI berlangsung dengan baik sesuai dengan skenario pembelajaran sebagaimana telah direncanakan.

Deskripsi Data Prestasi Belajar Matematika Siswa

Data hasil tes prestasi belajar yang akan dideskripsikan terdiri atas data pretest dan posttest yang disajikan pada Tabel 3. Pretest merupakan tes yang diberikan pada dua kelompok sebelum dilaksanakan model pembelajaran. Tes ini bertujuan untuk mengetahui kemampuan awal siswa pada materi "memahami sifat bangun ruang sederhana dan hubungan antarbangun datar". Posttest dilaksanakan setelah dilaksanakan model pembelajaran. Tes ini bertujuan untuk mengetahui peningkatan prestasi belajar siswa setelah dilaksanakan model pembelajaran.

Tabel 3.Tabel 3 Rata-rata, Standar Deviasi, Skor Tertinggi yang Mungkin, Skor Terendah yang Mungkin, Skor Maksimum Ideal, Skor Minimum Ideal, Ketuntasan, Peningkatan Ketuntasan

\begin{tabular}{lcccc}
\hline \multirow{1}{*}{ Deskripsi } & \multicolumn{2}{c}{ STAD } & \multicolumn{2}{c}{ TAI } \\
\cline { 2 - 5 } & Pretest & Posttest & Pretest & Posttest \\
\hline Rata-rata & 60,87 & 78,35 & 66,48 & 75,81 \\
$\begin{array}{l}\text { Standar Deviasi } \\
\begin{array}{l}\text { Skor tertinggi } \\
\text { yang mungkin }\end{array}\end{array}$ & 11,18 & 8,78 & 11,98 & 7,59 \\
$\begin{array}{l}\text { Skor terendah } \\
\text { yang mungkin }\end{array}$ & 36 & 63 & 83 & 96 \\
$\begin{array}{l}\text { Skor tertinggi } \\
\text { ideal }\end{array}$ & 100 & 100 & 100 & 100 \\
$\begin{array}{l}\text { Skor terendah } \\
\text { ideal }\end{array}$ & 0 & 0 & 0 & 0 \\
$\begin{array}{l}\text { Ketuntasan } \\
\begin{array}{l}\text { Peningkatan } \\
\text { ketuntasan }\end{array}\end{array}$ & $26 \%$ & $87 \%$ & $43 \%$ & $86 \%$ \\
\hline
\end{tabular}

Hasil Uji Hipotesis

Uji Asumsi

Penghitungan normalitas data dilakukan dengan menggunakan uji KolmogrovSmirnov yang diolah dengan menggunakan program SPSS 17.0 for Windows. Cara yang digunakan untuk melakukan interpretasi output hasil analisis Kolmogrov-Smirnov adalah dengan kriteria keputusan: apabila nilai probabilitas lebih besar dari 0,05 maka populasi yang diperoleh berdistribusi normal, sedangkan bila nilai probabilitas kurang dari 0,05 maka populasi data yang diperoleh tidak berdistribusi normal.

Uji normalitas yang dilakukan menunjukkan bahwa data pretest model pembelajaran kelompok STAD dan TAI lebih besar dari nilai probabilitas 0,05 yaitu 0,200 dan 0,138 yang menyatakan bahwa data pretest pada masingmasing kelompok berdistribusi normal.

Sedangkan uji normalitas pada data posttest siswa dengan menggunakan model pembelajaran kooperatif tipe STAD dan tipe TAI probabilitasnya berturut-turut adalah 0,200 dan 0,200 yang masing-masing lebih besar dari 0,05 . Hal ini menunjukkan bahwa hasil posttest dari masing-masing kelompok berdistribusi normal.

Berdasarkan data observasi aktivitas belajar siswa, diketahui bahwa uji normalitas yang ditampilkan menggunakan Metode Kolmogorov-Smirnov skor signifikansi. (p) lebih besar dari $\alpha=0,05$. Karena skor signifikasi penilaian aktivitas sebelum dan sesudah dilakukan model pembelajaran pada kelas eskperimen lebih besar dari 0,05 yaitu 0,067>0,05 dan 0,200>0,05 maka dapat disimpulkan bahwa kedua kelompok data tersebut berdistribusi normal.

Uji homogenitas dilakukan dengan menggunakan test of homogeneity of variance dengan menggunakan bantuan program SPSS 17.0 for windows. Hasil uji homogenitas pretest dan posttest dengan lavene statistic diperoleh nilai probabilitas lebih besar dari 0,05 yaitu $0,169>0,05$ sehingga dapat disimpulkan kedua data adalah homogen.

Hasil penilaian aktivitas belajar sebelum dan sesudah eksperimen juga dilakukan uji homogenitas menggunakan test of homogeneity of variance. Hasil uji homogenitas dengan lavene statistic tentang penilaian aktivitas belajar sebelum dan sesudah eksperimen diperoleh nilai probabilitas lebih dari 0,05 yaitu $0,657>$ 0,05 sehingga dapat disimpulkan kedua data adalah homogen.

\section{Uji Keefektifan}

Sebelum melakukan analisis untuk uji keefektifan model pembelajaran kooperatif tipe 
STAD dibandingkan dengan tipe TAI, terlebih dahulu dilakukan uji keefektifan model pembelajaran kooperatif tipe STAD dan tipe TAI dengan one sample t-test. Uji keefektifan ini bertujuan untuk mengetahui efektif tidaknya model pembelajaran kooperatif tipe STAD dan tipe TAI masing-masing ditinjau dari aktivitas pembelajaran dan prestasi belajar siswa terhadap mata pelajaran Matematika.

Pengujian hipotesis tahap pertama, yaitu menguji keefektifan model pembelajaran kooperatif STAD ditinjau dari prestasi belajar. Berdasarkan hasil analisisdenganone samplettest menggunakan aplikasi SPSS 17.0 for windows didapatkan nilai signifikansi lebih kecil dari 0,05. Jadi, dapat disimpulkan bahwa model pembelajaran kooperatif tipe STAD efektif ditinjau dari prestasi belajar siswa.

Pengujian hipotesis tahap kedua, yaitu menguji keefektifan model pembelajaran kooperatif STAD dtinjau dari aktivitas belajar siswa. Berdasarkan hasil analisisdengan one samplet-test menggunakan aplikasi SPSS 17.0 for windows didapatkan nilai signifikansi lebih kecil dari 0,05. Jadi, dapat disimpulkan bahwa model pembelajaran kooperatif tipe STAD efektif ditinjau dari aktifitas belajar siswa.

Pengujian hipotesis tahap ketiga, yaitu menguji keefektifan model pembelajaran kooperatif TAI ditinjau dari prestasi belajar. Berdasarkan hasil analisis dengan one samplettest menggunakan aplikasi SPSS 17.0 for windows didapatkan nilai signifikansi lebih kecil dari 0,05. Jadi, dapat disimpulkan bahwa model pembelajaran kooperatif tipe TAI efektif ditinjau dari prestasi belajar siswa.

Pengujian hipotesis tahap keempat, yaitu menguji keefektifan model pembelajaran kooperatif TAI ditinjau dari aktivitas belajar. Berdasarkan hasil analisis dengan one samplettest menggunakan aplikasi SPSS 17.0 for windows didapatkan nilai signifikansi lebih kecil dari 0,05. Jadi, dapat disimpulkan bahwa model pembelajaran kooperatif tipe TAI efektif ditinjau dari aktifitas belajar siswa.

Uji Perbedaan Keefektifan Model Pembelajaran

Untuk mengetahui perbedaan keefektifan kelompok pembelajaran kooperatif tipe STAD dengan tipe TAI ditinjau dari aktivitas dan prestasi belajar siswa dilakukan uji multivariat menggunakan statistik Hotelling's $T^{2}$ dengan bantuan program SPSS 17.0 for windows.
Pada uji multivariat sebelum diterapkan model pembelajaran berdasarkan hasil analisis SPSS 17.0 for windows diperoleh nilai signifikansi $=0,116>0,05$ sehingga dapat disimpulkan bahwa Ho diterima dan Ha ditolak. Artinya tidak terdapat perbedaan keefektifan model kooperatif pada kelas yang akan diterapkan model pembelajaran kooperatif tipe STAD dan tipe TAI ditinjau dari aktifitas dan prestasi belajar siswa.

Pada uji multivariat sesudah diterapkan model pembelajaran berdasarkan hasil analisis SPSS 17.0 for windows diperoleh nilai signifikansi $=0,111>0,05$ sehingga dapat disimpulkan bahwa Ho diterima dan Ha ditolak. Artinya tidak terdapat perbedaan keefektifan model kooperatif pada kelas yang diterapkan model pembelajaran kooperatif tipe STAD dan TAI ditinjau dari aktifitas dan prestasi belajar siswa.

Untuk mengetahui tingkat keefektifan dari model pembelajaran kooperatif tipe STAD dan TAI mengacu pada kriteria ketuntasan minimal (KKM). KKM untuk mata pelajaran matematika adalah 70,00. Model pembelajaran kooperatif tersebut efektif apabila rerata prestasi belajar siswa di atas KKM yaitu 70,00.

Untuk mengetahui keefektifan model pembelajaran tipe STAD tersebut dilakukan uji statistik dengan uji one sample t-test yang menunjukkan skor $t_{\text {hitung }}$ lebih besar dari $t_{\text {tabel }}$ yaitu 42,779 > 2,07 yang berarti Ho ditolak dan Ha diterima sehingga dapat disimpulkan bahwa model pembelajaran kooperatif tipe STAD efektif ditinjau dari prestasi belajar siswa.

Adapun model pembelajaran kooperatif STAD ditinjau dari aktivitas belajar melalui hasil observasi menunjukkan kriteria hasil penilaian yang sangat tinggi dengan skor 15,34 serta hasil uji dengan one sample t-test menunjukkan bahwa skor $t_{\text {hitung }}$ lebih besar dari $t_{\text {tabel }}$ yaitu 32,939 > 2,09 yang berarti Ho ditolak dan Ha diterima sehingga dapat disimpulkan bahwa model pembelajaran kooperatif STAD efektif ditinjau dari aktivitas belajar siswa. Individu yang saling berkontribusi aktif dalam pembelajaran, adanya kesadaran bekerja sama antar anggota, saling ketergantungan positif serta saling mengajarkan keterampilan sosial interaksional berpengaruh pada peningkatan prestasi belajar siswa yang mendukung keberhasilan pembelajaran matematika.

Selain itu, pemberian penghargaan berupa piagam dan hadiah berupa pensil pada kelompok terbaik membuat siswa senang dan dapat memacu siswa untuk belajar lebih baik 
lagi. Hal tersebut didukung pernyataan dalam buku yang ditulis Santrock (2011, p.342) yaitu, "When the conditions of group rewards and individual accountability are met, cooperative learning improves achievement across different grades and in tasks that range from basic skills to problem solving".

Untuk mengetahui keefektifan model pembelajaran kooperatif tipe TAI dilakukan uji statistik dengan uji one sample t-test menunjukkan skor $t_{\text {hitung }}$ lebih besar dari $t_{\text {tabel }}$ yaitu 45,750 > 2,07 yang berarti Ho ditolak dan Ha diterima sehingga dapat disimpulkan bahwa model pembelajaran kooperatif tipe TAI efektif ditinjau dari prestasi belajar siswa.

Adapun model pembelajaran kooperatif TAI ditinjau dari aktivitas belajar melalui hasil observasi menunjukkan kriteria hasil penilaian yang sangat tinggi dengan skor 16,29. Selain itu setelah dilakukan uji statistik dengan uji one sample t-test menunjukkan bahwa skor $t_{\text {hitung }}$ lebih besar dari $t_{\text {tabel }}$ yaitu 24,404 > 2,09 yang berarti bahwa Ho ditolak dan Ha diterima sehingga dapat disimpulkan bahwa model pembelajaran kooperatif tipe TAI efektif ditinjau dari aktifitas belajar siswa. Model pembelajaran TAI efektif dikarenakan siswa berpartisipasi aktif dalam pembelajaran matematika melalui diskusi dengan anggota kelompoknya, mengerjakan LKS terlebih dahulu secara individu sehingga dapat menemukan sendiri berbagai teori dan memahami materi yang dipelajarinya dengan lebih baik, kemudian siswa mendiskusikan hasil kerja LKS dalam kelompoknya masing-masing untuk saling memeriksa dan memberikan masukan terhadap pekerjaannya. Hal inilah yang menyebabkan model pembelajaran kooperatif tipe TAI efektif ditinjau dari aktivitas belajar dan prestasi belajar siswa.

Untuk mengetahui model mana yang lebih berpengaruh terhadap aktivitas belajar dan prestasi belajar siswa maka perlu dibandingkan hasil posttest dari kedua kelompok eksperimen.

Berdasar hasil uji hipotesis multivariat Hotelling's $T^{2}$ dengan bantuan program SPSS 17.0 for windows menunjukkan bahwa nilai probabilitas lebih kecil dari taraf signifikansi $=$ $0,111>0,05$ sehingga hipotesis yang berbunyi "tidak terdapat perbedaan keefektifan model pembelajaran STAD dan TAI ditinjau dari aktivitas belajar dan prestasi belajar siswa" diterima dan Ha ditolak. Artinya tidak terdapat perbedaan keefektifan model kooperatif tipe STAD dan TAI ditinjau dari aktifitas dan prestasi belajar siswa. Dengan kata lain model pembelajaran kooperatif tipe STAD tidak lebih efektif dibandingkan dengan TAI.

Apabila ditinjau dari rata-rata nilai posttest untuk penilaian prestasi belajar siswa, pada model pembelajaran STAD dan TAI menunjukkan perbedaan yaitu masing-masing 78,35 dan 75,81 . Namun, sesuai yang dijelaskan oleh Erickson \& Nosanchuk (1987, p.47) bahwa untuk maksud eksplorasi rata-rata tidak tepat, karena ia membutuhkan lebih banyak perhitungan dibanding taraf yang lain, dan lebih penting lagi rata-rata tidak tangguh. "Tidak tangguh" berarti terdapat data ekstrim yang akan sangat memengaruhi besarnya rata-rata.

Standar deviasi pada nilai posttest untuk penilaian prestasi belajar siswa tampak adanya perbedaan yaitu untuk STAD adalah 8,78 dan untuk TAI adalah 7,59 yang menunjukan bahwa data pada nilai posttest STAD cenderung menyebar, hal ini mengacu pada pernyataan Erickson \& Nosanchuk (1987, p.56) yaitu bahwa semakin menyebar harga angkatan semakin besar deviasinya. Apabila standar deviasinya kecil, maka hal tersebut menunjukkan nilai sampel dan populasi berkumpul atau mengelompok di sekitar nilai rata-rata hitungnya. Artinya karena nilainya hampir sama dengan nilai rata-rata, maka disimpulkan bahwa anggota sampel atau populasi memunyai kesamaan. Sebaliknya, apabila nilai deviasinya besar, maka penyebarannya dari nilai tengah juga besar.Hal tersebut menunjukkan adanya nilai-nilai ekstrim baik yang tinggi maupun rendah.Standar deviasi yang besar juga menunjukkan adanya perbedaan jauh diantara anggota populasi. Oleh sebab itu, walaupun rata-rata data nilai posttest untuk penilaian prestasi belajar siswa dengan model pembelajaran STAD lebih tinggi yaitu 78,35 daripada TAI 75,81, tetapi hal ini menjadi kurang baik karena standar deviasi STAD lebih besar daripada TAI yang menunjukkan ada kemungkinan terdapat nilai yang ekstrim.

Sedangkan apabila ditinjau dari aktivitas belajar matematika siswa skor menunjukkan bahwa rata-rata STAD adalah 15,34 yang termasuk dalam kriteria penilaian sangat tinggi dan TAI adalah 16,29 yang termasuk dalam penilaian kriteria tinggi. Kriteria pada kedua model pembelajaran kooperatif ini di atas rata-rata kriteria sedang sehingga pembelajaran tersebut keefektifannya sama dengan selisih skor yang tidak signifikan.

Ada beberapa kemungkinan yang menyebabkan hasil penelitian tidak sejalan dengan 
dugaan awal peneliti. Kemungkinan tersebut antara lain pelaksanaan pembelajaran pada kedua tipe tidak terlalu lama, sehingga pengaruhnya belum begitu tampak. Pelaksanaan pembelajaran yang tidak maksimal seperti pengelolaan waktu yang tidak sesuai dengan rencana pelaksanaan pembelajaran (RPP). Aktivitas belajar siswa pada kedua kelompok eksperimen sama yaitu menggunakan alat bantu lembar kegiatan siswa (LKS) yang sama, yang membedakan adalah proses pembelajarannya atau tahap-tahap pembelajaran. Ketika presentasi, untuk kelas STAD, peserta didik masih saling menunjuk rekannya dan malu untuk memresentasikan jawabannya. Sedangkan untuk kelas TAI, diskusi kelompok masih didominasi oleh siswa yang lebih pandai karena siswa yang kurang pandai merasa minder untuk menyampaikan pendapatnya.

\section{Simpulan dan Saran}

Simpulan

Secara umum dari uraian di atas dapat disimpulkan bahwa kedua model pembelajaran baik model pembelajaran STAD maupun TAI efektif ditinjau dari aktivitas dan prestasi belajar matematika siswa. Selain itu, kedua model pembelajaran kooperatif tersebut tidak memunyai perbedaan keefektifan ditinjau dari prestasi dan aktivitas belajar matematika siswa di kelas IV SD. Hasil ini memerkuat pendapat Borich (2007, p.390) yaitu, "Many different forms of cooperative learning have been successfully used in classrooms of all grade levels and subject matter", yang berarti berbagai bentuk pembelajaran kooperatif telah berhasil digunakan di ruang kelas dari semua tingkatan kelas dan materi pelajaran.

Saran

Berdasarkan simpulan dan dengan memerhatikan implikasi dari penelitian, maka saran yang dapat disampaikan adalah sebagai berikut: (1) untuk sekolah, guru, dan mahasiswa hendaknya dapat menerapkan metode pembelajaran yang tepat dan lebih bervariasi yang memungkinkan siswa berpartisipasi aktif dalam pembelajaran dan dapat memeroleh prestasi belajar yang lebih baik dan (2) disarankan kepada guru matematika khususnya untuk menggunakan model pembelajaran kooperatif tipe $S T A D$ dan/atau model pembelajaran kooperatif tipe TAI untuk meningkatkan aktivitas dan prestasi belajar siswa yang optimal.

\section{Daftar Pustaka}

Arends. (2008). Belajar untuk mengajar. (Terjemahan Helly Prajitno Soetjipto \& Sri Mulyantini Soetjipto). New York: McGraw Hill Companies, Inc. (Buku asli diterbitkan tahun 2007).

Arends, R. I.\& Kilcher, A. (2010). Teaching for student learning; becoming an accomplished teacher. New York: Taylor \& Francis.

Azwar, S. (2012). Tes prestasi. Yogyakarta: Pustaka Pelajar.

Borich, G. D. (2007). Effective teaching methods "research-based practise". Ohio: Pearson Education Inc.

Badan Standar Nasional Pendidikan (BSNP). (2006). Panduan penyusunan kurikulum tingkat satuan pendidikan jenjang pendidikan dasar dan menengah. Jakarta: BSNP.

Badan Standar Nasional Pendidikan (BSNP). (2006). Standar isi untuk satuan pendidikan dasar dan menengah. Jakarta: BSNP.

Daniel, M. (2004). Doing quantitative research in education. London: SAGA.

Davidson, N, Robertson, L, and Dees, R. L. (1991). Cooperative learning to support thinking, reasoning, and communicating in mathematics. Diambil pada tanggal 29 Juni 2013 dari

http://www.dm.unipi.it/perfezionamento/docum enti/ApprendimentoCooperativo/CLand Mathematics.pdf.

Erickson, B. H \& Nosanchuk, T. A. (1987). Memahami data. (Terjemahan dari R.K Sembiring \& Manasse Malo). Toronto: McGraw-Hill Ryerson Ltd. (Buku asli diterbitkan tahun 1977).

Hudojo, H. (1988). Mengajar Belajar Matematika. Jakarta: Depdikbud.

Johnson, D. W. \& Johnson, R. T. (1987). Learning together and alone: cooperative, competitive, and individualistic learning. Boston: Allyn and Bacon.

Kauchack, D. P. \& Eggen, P. D. (1998). Learning and teaching: research-based methods. $\left(3^{\text {rd }} e d\right)$. Boston: Allyn and Bacon. 
Kartowagiran, Badrun. (2011). Item and item analysis (ITEMAN). Bahan kuliah, tidak diterbitkan. Yogyakarta: Universitas Negeri Yogyakarta.

Marsigit. (2008). Pengembangan model pembelajaran matematika. Diambil tanggal 15 Juli 2012, dari

http://pbmmatmarsigit.blogspot.com/2008/12/p engembangan-model-pembelajaran.html.

Moore, K. D. (2009). Effective instructional strategies. Los Angeles: SAGE.

Muraya, D. N \& Kimamo, G. (2011). Effect of cooperative learning approach on biology mean achievement scores of secondary school students in machakos district, Kenya. Educational research and reviews vol. 6(12), pp. 726-745. Kenya: Catholic University of Eastern Africa.

Roebyanto, G \& Harmini, S. (2006). Pembelajaran geometri yang berorientasi pada teori van hiele dalam upaya meningkatkan pemahaman konsep segiempat. Jurnal penelitian kependidikan tahun 16 Nomor 1 Juni 2006.
Santrock, J.W. (2011). Educational psychology $\left(5^{\text {th }} e d\right)$. New York: Mc. Graw Hill.

Sardiman, A. M. (2004). Interaksi dan motivasi belajar mengajar. Jakarta: Raja Grafindo Persada.

Slavin, E. R. (1995). Cooperative learning: theory, research, and practise $\left(2^{\text {nd }} e d\right)$. London: Allyn \& Bacon.

Sugihartono, dkk. (2007). Psikologi pendidikan. Yogyakarta: UNY Press.

Suherman, E \& Winataputra, U. S. (1992). Strategi belajar mengajar matematika. Jakarta: Depdikbud.

Widdiharto, R. (2004). Modul diklat guru pemandu/pengembang SMP di daerah jenjang dasar, dirjend peningkatan mutu pendidikan dan tenaga kependidikan. Yogyakarta: PPPTK Matematika.

Widyantini, Th. (2006). Model pembelajaran matematika dengan pendekatan kooperatif. Yogyakarta: PPPTK Matematika.

Zakaria, E., Chin, L. C., \& Daud, M. Y. (2010). The effects of cooperative learning on students mathematics achievement and attitude towards mathematics. Journal of social science, 6, 272-275. 